Nowoczesne Systemy Zarządzania

Zeszyt 12 (2017), nr 4 (październik-grudzień)

ISSN 1896-9380, s. 31-45

Modern Management Systems

Volume 12 (2017), No. 4 (October-December)

ISSN 1896-9380, pp. 31-45
Instytut Organizacji i Zarządzania

Wydział Cybernetyki

Wojskowa Akademia Techniczna

w Warszawie

Institute of Organization and Management Faculty of Cybernetics

Military University of Technology

\title{
Czynnik ludzki istotnym elementem we współczesnej organizacji
}

\author{
Human factor - crucial element \\ in the contemporary organization
}

\author{
Wiesława Załoga \\ Wojskowa Akademia Techniczna \\ Zbigniew Ciekanowski \\ zbigniew@ciekanowski.pl
}

Państwowa Szkoła Wyższa im. Papieża Jana Pawła II w Białej Podlaskiej

\begin{abstract}
Abstrakt: W opracowaniu na temat Czynnik ludzki istotnym elementem we współczesnej organizacji przedstawiono na wstępie, jak rozwijały się zasoby ludzkie w czasie kilku wieków. Następnie pokazano też, jak ważne dla organizacji są zasoby ludzkie, a także wybór zespołu pracowniczego, który jest podstawą poprawnego działania oraz swoistym bodźcem do rozwoju organizacji. Człowiek, wnosząc swoje umiejętności i specjalistyczną wiedzę, angażuje się w istotne dla organizacji sprawy. Przedstawiono również, jak istotne jest inwestowanie w zasoby ludzkie oraz utrzymanie dobrze wyszkolonych osób w obrębie organizacji. Jest to ważna część całego procesu zatrudnienia. Pracodawca, dbając o swoich pracowników, pośrednio dba o własną organizację. Na zakończenie przedstawiono wnioski, które jednoznacznie pokazują, że zasoby ludzkie w organizacji stanowią najważniejszy jej czynnik. Wiedza i umiejętności pracowników przekładają się na wyniki finansowe organizacji. Inwestycje w kapitał ludzki otwierają wielkie możliwości rozwoju w każdym przedsiębiorstwie, ale jednocześnie ich brak sprawia, że organizacja stoi w miejscu.

Słowa kluczowe: kapitał, ludzie, organizacja, pracodawca, wiedza.
\end{abstract}

Abstract: In the elaboration Human factor with crucial element in the contemporary organization first was presented the development of human resources in the course of a few centuries. Then it was showed how important human resources are for an organization and how significant is the selection of the crew as it is not only the base for proper fulfilling tasks but also serves as a peculiar stimulant to its development. A person by introducing his skills and specialized knowledge gets involved in the important company matters. It was also stressed how important thing is to invest into human resources and to keep trained staff within the company. These are a key element of the employment process. An employer by taking 
care of his employees indirectly is taking care of his company. At the end all conclusions were introduced which unambiguously show that human resources constitute the company's most important factor. The knowledge and skills is synonymous to financial results of a company. Investments into human resources open great perspectives and their lack hamper its development.

Keywords: capital, people, organization, employer, knowledge.

\section{Wstęp}

Od kilkuset lat jednym z najważniejszych obiektów obserwacji wielkich myślicieli i naukowców jest człowiek. Niewątpliwie liczne badania przybliżają każdą osobę do poznania samego siebie i co najistotniejsze do określenia swoich wszystkich możliwości. Na przełomie wieków uczeni wielokrotnie próbowali określić granice ludzkiego umysłu i ciała. Zdumiewający może okazać się fakt, że postawione przez nich tezy najczęściej były podważane przez ludzkie dokonania. Ciężka praca nad sobą, zdobywanie doświadczenia oraz chęć rozwoju są kluczowymi czynnikami przekraczania granic możliwości, początkowo uznawanych za nierealne. W dobie płynnego przepływu informacji wielokrotnie jesteśmy szokowani wyczynami pojedynczych jednostek. Te fascynujące czyny pokazują znaczenie człowieka w każdej dziedzinie życia. Zaangażowanie oraz włożony wysiłek pozwalają na realizację coraz ambitniejszych celów oraz nieustanny rozwój. Umiejętności człowieka, jego wiedza i cechy szczególne uznawane są obecnie za najważniejszy czynnik postępu. Właśnie dzięki nim istota ludzka od początku naszych dziejów mogła się rozwijać - początkowo udoskonalając proces zdobywania pożywienia, aż do czasów współczesnych, w których bierze czynny udział w rozwoju przedsiębiorstwa. Peter Drucker, uważany za ojca nowoczesnej teorii zarządzania, posuwa się nawet dalej, określając zasoby ludzkie jako kluczowy czynnik produkcji, według niego tradycyjne zasoby - ziemia, kapitał, praca - powoli stają się raczej przeszkodami w dążeniu do rozwoju przedsiębiorstwa (Hejduk, 2000, s. 73).

\section{Rozwój zasobów ludzkich}

Zapoczątkowane w XVIII wieku ogromne zmiany w czasie rewolucji przemysłowej w Anglii na zawsze udoskonaliły proces produkcji. Jednak dopiero na przełomie XIX i XX wieku zostało zauważone znaczenie czynnika ludzkiego w rozwoju przedsiębiorstwa. Najcenniejszym zasobem firmy w XIX wieku były maszyny i urządzenia wraz ze sposobami ich wykorzystania w produkcji, określonymi regułami hierarchicznej organizacji. W XXI wieku najcenniejszym zasobem każdej organizacji, zarówno w sektorze biznesu, jak i poza nim są pracownicy umysłowi i ich wydajność (Drucker, 2000, s. 141). Dbanie o ten czynnik oraz poszukiwanie odpowiedniego kapitału ludzkiego stało się nadrzędnym celem każdego przedsiębiorstwa. Zgodnie z teorią Adama Smitha jednym z niezbędnych zasobów do 
rozpoczęcia i prowadzenia działalności gospodarczej jest czynnik ludzki. W literaturze naukowej można wyróżnić dwa sposoby nazewnictwa pozycji człowieka w organizacji - jako zasób oraz kapitał ludzki przedsiębiorstwa. Obydwa pojęcia dotyczą głównie elementu ludzkiego w organizacji. Występują niewielkie różnice w sposobie definiowania, jednak w swojej książce Kapitał ludzki i wzrost gospodarczy Stanisław Domański łączy dwa podejścia w jedną całość: czynnik ludzki w organizacji oznacza według niego zasób wiedzy, umiejętności, zdrowia i energii witalnej zawartej w społeczeństwie, który można powiększać drogą inwestycji w rozwój człowieka. Jest również wskaźnikiem możliwości produkcyjnych i kreatywności pojedynczej jednostki lub grupy osób. Warto nadmienić, że stanowi część swojego posiadacza i co za tym idzie, jest z nim trwale związany (Domański, 1993, s. 19). Ta cecha pozwala odróżnić go od kapitału rzeczowego, gdyż nie może on zmienić właściciela, bo nie podlega obrotowi. Jedną z najważniejszych cech zasobów ludzkich jest aspekt ich rozwoju. W porównaniu z innymi zasobami przedsiębiorstwa mogą pomnażać swoją wartość, gdy inne zasoby w trakcie wykorzystania deprecjonują się (Ciekanowski, 2014, s. 168). Już samo pojęcie kapitału ludzkiego ukazuje rolę pracowników w procesie funkcjonowania organizacji. Ludzie pracujący $\mathrm{w}$ organizacji oraz ich wiedza i umiejętności wpływają na wykorzystanie innych zasobów organizacji (rzeczowych i naturalnych). Jest to jeden $z$ argumentów za znaczeniem kapitału ludzkiego w organizacji. Wszystkie zasoby organizacji przenikają się, a co za tym idzie, prawidłowe funkcjonowanie przedsiębiorstwa jest możliwe do osiągnięcia tylko w sytuacji, gdy kapitał rzeczowy, naturalny oraz ludzki są na odpowiednim poziomie. Jednak przedsiębiorstwo posiadające tylko dwa pierwsze zasoby jest skazane na porażkę, gdyż bez wykwalifikowanej kadry pracowniczej organizacja (przedsiębiorstwa, firmy) nie będzie wykorzystywała optymalnie swoich możliwości, nie otworzy się na innowacje, a także jej oferta nie będzie konkurencyjna wobec innych podmiotów na rynku.

Wpływ zasobów ludzkich na sytuację i rozwój organizacji można rozpatrywać w czterech skalach (Ludwiczyński, 2008, s. 110):

- makro, która obrazuje ogromny wpływ wielkości i struktury kapitału ludzkiego na rozwój społeczeństwa, narodów, a nawet ludzkości. W szczególności odnosi się do wpływu na innowacyjność gospodarki i społeczeństwa jako całości. Kształtuje nowoczesną infrastrukturę techniczno-organizacyjną, informatyczną oraz socjalną (Król, 2008, s. 111-112);

- indywidualnej - wskazuje na inwestycje ludzi w samych siebie, a poprzez akumulację różnego typu nakładów (edukacja, wiedza i doświadczenie) zwiększanie się wartości pracownika na rynku oraz jego ogólnej produktywności (Dobija, 2003, s. 119);

- zespołu, dotyczy wpływu członków zespołu pracowniczego i stanowi sumę kapitałów indywidualnych ludzi należących do zespołu. Kapitał ludzki w tej skali jest ściśle związany z poprawnym kierowaniem zespołem. Wynik pracy 
zależy nie tylko od kapitału ludzkiego, ale przede wszystkim od prawidłowego zarządzania;

- organizacji - wskazuje na rozwój przedsiębiorstwa dzięki indywidualnym kapitałom ludzkim pracowników lub zespołu, z uwzględnieniem efektu synergii $\mathrm{z}$ technologią, techniką czy inną organizacją. $\mathrm{W}$ tym aspekcie zarządzanie odgrywa również bardzo znaczącą rolę (Ludwiczyński, Król, 2008, s. 115-116).

W każdej z czterech skal łatwo dostrzegalny jest wpływ kapitału ludzkiego na przedsiębiorstwo. W ujęciu makro wzrost zasobów ludzkich skutkuje zwiększeniem innowacyjności, poprawą infrastruktury, sprzyja upowszechnieniu nowoczesnych wzorców produkcji i zarządzania. W skali indywidualnej progres kapitału ludzkiego przedstawia rozwój jednostki, który przekłada się na zwiększenie produkcji przedsiębiorstwa. Obrazuje tym samym największą zaletę płynącą z inwestowania w pojedyncze jednostki organizacji (poprzez liczne kursy, spotkania, warsztaty), czyli zysk. Kapitał ludzki zarówno w organizacji, jak i zespole wpływa na zwiększenie się możliwości produkcyjnych oraz innowacyjnych danej grupy. Opisany wyżej wpływ zasobów ludzkich na przedsiębiorstwo doskonale przedstawia ich znaczenie w funkcjonowaniu firmy. Bardzo ważnym elementem długookresowej działalności każdej organizacji jest inwestowanie w ludzi. Przedsiębiorstwa starające się o utrzymanie na rynku, poprawę konkurencyjności, ale także rozwój i ekspansję nie mogą pozwolić sobie na straty wiążące się z brakiem inwestycji i rozwoju zasobów ludzkich. Brak inwestycji w czynnik ludzki najczęściej uniemożliwia osiągnięcie celów długookresowych, a co za tym idzie, oznacza nieustanny spadek konkurencyjności organizacji.

Wzrost kosztów w stosunku do innych przedsiębiorstw jest jednym z efektów złej polityki personalnej firmy. W sytuacji niewystarczających inwestycji w zasoby ludzkie firma traci innowacyjność swoich produktów, ale także nie dokonuje unowocześnień w procesie produkcji. Celem każdej firmy jest ograniczenie kosztów i zwiększenie zysków. Mogłoby się wydawać, że zmniejszenie środków przeznaczanych na rozwój kapitału ludzkiego jest elementem tzw. cięcia kosztów, jednak jest to działanie doraźne i w długoterminowym ujęciu może spowodować olbrzymie straty. Funkcjonowanie tej zasady najlepiej obrazuje przykład kalifornijskiej firmy Apple, która w latach 1986-90 zdominowała rynek technologiczny, stając się jednym $\mathrm{z}$ największych przedsiębiorstw $\mathrm{w}$ historii kapitalizmu. Wprowadzenie nowoczesnego na tamte lata oprogramowania w swoich komputerach Macintosh I i Macintosh II było efektem doskonałej współpracy zespołu pracowników. W tym przypadku współzałożyciel firmy Steve Jobs poprzez inwestycje i dobór odpowiednich ludzi oraz posiadanego przez nich kapitału ludzkiego zmienił całkowicie postrzeganie i funkcjonowanie komputera personalnego w przyszłości. Istotą znaczącego rozwoju firm oprócz nastawienia na innowacyjność produktu i odpowiednie zrozumienie rynku technologicznego było udoskonalenie procesu produkcji, zaczerpniętego z fabryk japońskich firm technologicznych, co pozwoliło zmniejszyć koszty produkcji 
(Issacson, 2012, s. 29). W ten sposób firma Apple, inwestując w zasoby ludzkie swojego przedsiębiorstwa, wyprzedziła konkurencję (Microsoft) pod względem technologii i produkcyjnym o kilka lat. Ten przykład idealnie pokazuje znaczenie inwestycji w zasoby ludzkie dla organizacji nastawionej na rozwój.

Kolejnym negatywnym skutkiem niedoboru inwestycji w zasoby ludzkie jest ograniczanie możliwości rozwoju przedsiębiorstwa. We współczesnych czasach sytuacja na rynku zmienia się bardzo dynamicznie, a firmy, które nie dostosowują się do rynku, tracą dystans do konkurencji i w efekcie swój udział w nim. Inwestycje w kapitał finansowy, rzeczowy i naturalny nie wpływają tak znacząco na rozwój przedsiębiorstwa jak inwestycje w ludzkie zasoby. To właśnie pracownicy mają największy wpływ na pozytywne zmiany w organizacji, ponieważ tworzenie nowych produktów, udoskonalanie obecnych oraz korekty w procesie produkcji wywodzą się od pomysłowości oraz zaangażowania czynnika ludzkiego. Te aspekty sprawiają, że dana firma jest skłonna do rozwoju lub nie. Przedsiębiorstwo powinno postrzegać pracownika jako aktywa, ponieważ przez swoją pracę generują one część dochodu, co przekłada się w przyszłości na zysk. Pamiętać trzeba jednak, że człowiek bez odpowiedniego zaplecza technicznego nie wykorzystuje w pełni swoich możliwości. Dlatego też inwestycje jedynie w kapitał ludzki i jego rozwój mogą nie przynieść oczekiwanych rezultatów.

Inwestycje w zasoby ludzkie można podzielić w następujący sposób (Lipka, 2010, s. 131-165):

- inwestycje $\mathrm{w}$ formułowanie i redefiniowanie strategii personalnej wyznaczające kierunki inwestowania;

- inwestowanie w szkolenia, które odnoszą się do przygotowania procesów szkolenia;

- inwestycje dotyczące utrzymania i zwiększania wiedzy w przedsiębiorstwie. Polegają na gromadzeniu i wykorzystywaniu wiedzy do realizacji celów organizacji;

- inwestowanie w marketing personalny, mające na celu przyciągnięcie utalentowanego kapitału ludzkiego;

- inwestycje retencyjne mające na celu utrzymanie pracowników i zwiększenie zaufania oraz lojalności;

- inwestowanie w poprawę warunków pracy, co przekłada się na zmniejszenie czynników szkodliwych;

- inwestowanie w coaching, może polegać na wykupieniu warsztatów dla kadry pracowniczej lub wynajęciu coacha, którego zadaniem jest motywacja i zwiększenie ambicji pracowników;

- inwestycje w przedsiębiorczość, ten rodzaj wspomagania kapitału ludzkiego ma wielki wpływ na ograniczanie kosztów stałych przedsiębiorstwa. Pracownicy nie marnotrawią kapitału rzeczowego, a co za tym idzie, koszty sztucznie nie rosną; 
- inwestowanie w kulturę organizacji;

- inwestycje w opiekę medyczną, zdrowotną oraz biologiczne potrzeby pracowników.

Inwestowanie $\mathrm{w}$ zasoby ludzkie przynosi wiele pozytywnych skutków dla przedsiębiorstwa. Oprócz czysto ekonomicznych aspektów prowadzenia polityki inwestowania w kapitał ludzki, występuje także zmniejszenie luki kompetencyjnej w przedsiębiorstwie, co przekłada się na wiele czynników. Między innymi praca w zespole, w którym każdy z członków jest na odpowiednim miejscu, posiada specjalistyczne umiejętności i wiedzę, a także jest pełen energii do działania, jest dużo efektywniejsza. Dobrze wybrana kadra oraz właściwy system motywowania pracowników przynosi wymierne korzyści w postaci większych zysków, a także zwiększenia elastyczności w przypadku jakichkolwiek problemów w funkcjonowaniu firmy. Dodatkowo inwestowanie w kapitał ludzki przedsiębiorstwa ma bardzo duże potencjalne korzyści w zakresie konkurencyjności organizacji w skali makroekonomicznej. Zmniejszenie kosztów stałych, wzrost innowacyjności oraz unowocześnienie procesów produkcji są jednymi z nich. Trzeba dodać, że wybór odpowiedniego zespołu jest podstawą dobrze funkcjonującego przedsiębiorstwa, a inwestycje w ten czynnik przynoszą znacznie większe i szybsze efekty w przypadku współpracy właściwych osób.

\section{Zasoby ludzkie a organizacja}

Zasoby ludzkie są najważniejszym zasobem każdej organizacji. Proces inwestycyjny rozpoczyna się już w trakcie poszukiwania i zatrudnienia pracownika. Bardzo ważne jest świadome wyszukiwanie potencjalnych współpracowników, co wiąże się z wybieraniem odpowiednich cech i odnalezieniem talentów oraz osób gotowych realizować ważne dla danej organizacji cele. To zadanie jest bardzo złożonym i skomplikowanym procesem. Dzieje się tak, ponieważ każdy człowiek posiada inne predyspozycje, kwalifikacje, poziom umiejętności i wiedzę, a wyselekcjonowanie odpowiednich kandydatów może przysporzyć dużo problemów. Wybór zespołu pracowniczego jest podstawą poprawnego działania, ale także swoistym bodźcem do rozwoju przedsiębiorstwa (Ciekanowski, 2013, s. 154). Człowiek, wnosząc swoje umiejętności i specjalistyczną wiedzę, angażuje się w istotne dla firmy sprawy. Niestety na przykładzie takiego państwa jak Polska szczególnie mali i średni przedsiębiorcy dopiero uczą się doceniać pracowników. Wyniki badań Eurofoundu pokazują korzystny trend w krajach Unii Europejskiej. Przedsiębiorstwa państw członkowskich wydają na szkolenia kadry najwięcej od piętnastu lat. W 2010 roku w kursach zapewnianych przez władze firmy brał udział już co trzeci pracownik („Dziennik Gazeta Prawna,” 2011, s. 1). Taka sytuacja pokazuje, jak ważnym elementem organizacji staje się kapitał ludzki. 
Wielu badaczy widzi w takiej sytuacji skutek małego stosunku wynagrodzeń pracowników do przychodów całego przedsiębiorstwa. Badania pokazują, że jedynie $11,4 \%$ przychodów firmy stanowią wynagrodzenia. Istotny dla gospodarki Polski jest fakt, że tylko 32,8\% pracowników korzysta ze szkoleń na koszt pracodawcy („Dziennik Gazeta Prawna”, 2011, s. 1). Polskie przedsiębiorstwa wypadają dość słabo na tle innych krajów członkowskich w tym aspekcie. Przekłada się to na małą konkurencyjność i efektywność przedsiębiorstw.

\section{Inwestycja w zasoby ludzkie}

Kolejnym elementem inwestycji w zasoby ludzkie jest utrzymanie dobrze wyszkolonych osób w obrębie organizacji. Jest to ważna część całego procesu zatrudnienia. Pracodawca, dbając o swoich podwładnych, pośrednio dba o własne przedsiębiorstwo. System motywacji, dobre warunki pracy oraz przyjazne stosunki w zespole procentują rozwojem firmy i zwiększeniem jej dochodu, ale przede wszystkim organizacja utrzymuje najważniejszy czynnik, czyli zasoby ludzkie, który razem z nią się rozwijał i zbierał bardzo wartościowe doświadczenia. Trzeba nadmienić, że występują dwa rodzaje takiej aktywności przedsiębiorstwa: motywowanie oraz system wynagrodzeń (Ludwiczyński, Król, 2008, s. 317). Analiza sytuacji, w której pracownicy kilku firm dysponują takimi samymi narzędziami, identycznymi umiejętnościami oraz pracują na podobnych stanowiskach, pokazuje, że występują dodatkowe czynniki oprócz zróżnicowania kapitału rzeczowego przedsiębiorstwa, wiedzy i zdolności pracowników. Motywowanie jest jedną z metod działalności władz firmy, dzięki której przy takim samym zapleczu produkcyjnym konkurencyjność firmy rośnie. To narzędzie jest szansą dla mniejszych i średnich firm. Motywując członków zespołu do wytężonej pracy i wykorzystywania w całości swojego kapitału ludzkiego, mogą zwiększyć swój udział w rynku. Efekt pracy składa się z trzech elementów:

- wiedzy i umiejętności;

- możliwości działania (kapitał rzeczowy);

- chęci do działania.

W dużym stopniu zarząd oraz sztab menedżerski jest w stanie zwiększyć jedną $\mathrm{z}$ trzech części efektu pracy jako całości, czyli chęć do działania. Jest to możliwe dzięki motywowaniu pracowników. Polityka firmy nastawiona na motywowanie pracowników dzieli się na trzy fazy. Pierwsza polega na odnalezieniu i przedstawieniu człowiekowi motywu. Natomiast w drugiej osoba pracująca w firmie dokonuje wyboru sposobu zachowania, które przyniesie mu rezultat oraz dąży do osiągnięcia danego celu. Ostatecznie pojawia się satysfakcja z realizacji zadania oraz osiągnięcia motywu.

Istnieją dwie najbardziej znane teorie motywacji pracowników: teoria $\mathrm{X}$ i $\mathrm{Y}$ McGregora oraz teoria potrzeb Maslowa. W pierwszej z nich wyróżniamy dwie 
odmienne postawy ludzi wobec pracy reprezentowane przez modele X i Y. Zgodnie $\mathrm{z}$ modelem X pracownicy traktują pracę jako przymus, starają się jej unikać. Nie mają żadnych ambicji. Zarządzający musi kontrolować ich i wręcz zmuszać do pracy poprzez groźby karami. Model Y opisuje pracę jako naturalną część życia. Człowiek chce pracować, realizować swoje ambicje i nie sprawia mu problemu branie na swoje „barki” odpowiedzialności. Angażuje się w sprawy firmy, kontroluje swoje zachowanie oraz dąży do osiągnięcia wytyczonych celów. Według McGregora teoria Y jest właściwa (Griffin, 1996, s. 80-81). Tworzenie atmosfery pracy oraz nieustanne motywowanie pracowników zapewnia ich zaangażowanie jak w modelu Y. Teoria potrzeb Maslowa opiera się na piramidzie potrzeb (Król, 2008, s. 317-361). Polega na grupowaniu potrzeb człowieka w ujęciu hierarchicznym w pięciu kategoriach potrzeb:

- fizjologicznych,

- bezpieczeństwa,

- przynależności,

- uznania,

- samorealizacji.

Teoria ta zakłada, że waga każdej kolejnej kategorii rośnie dopiero wraz z zaspokojeniem potrzeb niższego rzędu. Pracodawcy, dbając o potrzeby z najniższych szczebli piramidy, zapewniają fundament do rozwoju pracownika, co przekłada się na efektywność jego pracy i wzrost produktywności.

\section{Motywatory zasobów ludzkich w organizacji}

Jednym z narzędzi motywacyjnych jest zwiększenie wynagrodzenia. Można je podzielić na dwa rodzaje: bodźce krótkoterminowe i długoterminowe. Pierwszy z nich dotyczy wypłacania premii oraz nagród pieniężnych za osiągnięcie przez pracownika wyznaczonego celu. Jest to sposób na osiągnięcie chwilowej satysfakcji człowieka, ale co najważniejsze, nie nadwyręża w sposób drastyczny budżetu organizacji. Bodźce długoterminowe łączą się z długookresowym wzrostem płacy pracownika, jest to sposób motywacji na dłuższy czas pracy. Obydwa narzędzia przynoszą wymierne skutki w zwiększeniu możliwości kapitału ludzkiego przedsiębiorstwa - większa satysfakcja pracowników sprawia, że przychodzą oni do pracy pełni energii i chęci podejmowania nowych wyzwań. Przedsiębiorstwo, wypłacając wyższą płacę czy też premię, podnosi poziom dobrobytu pojedynczej osoby zatrudnionej w firmie. Taki człowiek czuje się spełniony, bezpieczny pod względem finansowym, ma poczucie, że jest potrzebny zespołowi. W ten sposób realizuje siebie i dąży do samorealizacji. Zwiększenie wynagrodzenia zachęca pracownika do dalszej i bardziej efektywnej pracy. Dodatkowo zaspokaja część potrzeb przedstawionych w piramidzie Maslowa. 
Oprócz zwiększenia płac podstawowych przedsiębiorstwo dysponuje możliwością przyznawania licznych przywilejów dla pracowników. Przykładem takiej polityki jest działalność firmy PKN Orlen, która zwiększyła wynagrodzenia w przypadku niezdolności do pracy dla pracowników ze stażem większym niż 25 lat. W trakcie choroby członkowie zespołu PKN Orlen otrzymują aż 100 procent wynagrodzenia, czyli o 20\% więcej niż przewiduje Kodeks pracy. Inne koncerny międzynarodowe również motywują swoich pracowników. Na przykład bank BPH przyznaje opcje na akcje dla pracowników, a koreański potentat technologiczny Samsung po przepracowaniu 10 i 15 lat w firmie nagradza ich 55-calowymi telewizorami 3D oraz laptopami („Dziennik Gazeta Prawna”, 2011, s. 3). Warto podkreślić, że organizacje mogą motywować i nagradzać pracowników nie tylko w finansowo-rzeczowy sposób. Świadczenia emerytalne, opieka nad dziećmi, zapewnienie ochrony zdrowia czy dłuższego urlopu macierzyńskiego to inne przykłady działalności firm nastawionych na rozwój i wzbogacanie kapitału ludzkiego. Należy nadmienić także, że znaczącym elementem zdecydowanego i ukierunkowanego rozwoju jest odpowiednie zarządzanie tym rodzajem kapitału.

Zarządzanie zasobami ludzkimi jest bardzo istotne w funkcjonowaniu przedsiębiorstwa, gdyż osoby kierujące organizacją zapobiegają w ten sposób marnotrawieniu kapitału ludzkiego, co stanowi nadrzędny cel menedżerów firmy. Zarządzanie kapitałem ludzkim jest związane z traktowaniem ludzi jako podstawowego zasobu organizacji, najistotniejszego aktywu. Do metod łączących się z tym zagadaniem dziedziny zarządzania należą: dobre porozumiewanie się z pracownikami, włączanie ich w bieżące problemy przedsiębiorstwa oraz dbałość o ich utożsamianie się z organizacją i lojalność w stosunku do niej. Nacisk położony jest na strategiczne podejście związane z pozyskiwaniem ludzi i kierowaniem nimi (Pocztowski, 2003, s. 36-37). Wszystkie sformułowane cele, strategie, programy działalności muszą uwzględniać warunki danej organizacji. Niestety nie jest możliwe stworzenie uniwersalnych reguł zarządzania kapitałem ludzkim we wszystkich firmach. Jest to spowodowane zmiennością i różnorodnością przedsiębiorstw oraz warunków ich otaczających, także każdorazowa zmiana tych warunków wpływa na odmienne podejścia do zarządzania kapitałem ludzkim w danej organizacji. System zarządzania zasobami ludzkimi w każdej konkretnej sytuacji musi uwzględniać specyficzne wymagania danej organizacji - jej strategię, strukturę, kulturę oraz uwarunkowania wewnętrzne i zewnętrzne (Ludwiczyński, Król, 2008, s. 56). Właściwe zarządzanie zasobami ludzkimi skoncentrowane na rozwoju potencjału każdego pracownika jest kluczowym czynnikiem trwałości, renomy i rozwoju przedsiębiorstwa. Z tego założenia wynika wysoka ranga problematyki doskonalenia umiejętności wszystkich zatrudnionych pracowników jako ważnego elementu funkcji personalnej w przedsiębiorstwie.

W przypadku każdej organizacji można określić specyficzny zespół cech i wartości, na które powinno być nakierowane zarządzanie kapitałem ludzkim. Ważnym elementem tego zespołu cech jest unikatowość wartości. Opisuje dążenie do tego, 
aby oferowane produkty i usługi odróżniały się od innych i były w jakiś sposób wyjątkowe. Następną cechą jest przełomowość wartości, wynikająca z kreowania nowych rynków, produktów oraz usług, co oznacza wyjście poza tradycyjne podejście do badania i zaspokajania potrzeb klientów i zastąpienie go unowocześnionym. Indywidualizacja jest kolejną wartością, na którą powinien być nastawiony sztab zarządczy przedsiębiorstwa. W nowoczesnej gospodarce $\mathrm{w}$ mniejszym stopniu produkty i usługi kierowane są do masowego odbiorcy, a coraz częściej do indywidualnych osób. Występuje konieczność produkcji „szytej na miarę” (Staniewski, 2008, s. 156-157).

Aby proces zarządzania zasobami ludzkimi w przedsiębiorstwie funkcjonował w prawidłowy sposób, pracodawca musi zainwestować w odpowiednich pracowników działu HR (Human Resources), co wiąże się z powiększeniem zasobów ludzkich firmy. Kierowanie kapitałem ludzkim organizacji jest ściśle zależne od umiejętności osób zatrudnionych. Pracodawca może szukać nowych pracowników poprzez dział HR lub doszkolić ich w ramach różnego typu projektów, programów i warsztatów. Znalezienie odpowiednich ludzi jest o tyle ważne, że przynosi późniejsze efekty, gdyż utalentowani pracownicy stanowią szczególne aktywa firmy. Obydwie drogi dają olbrzymie zyski, jednak inwestowanie w obecnych członków zespołu organizacji w ujęciu długookresowym nie tylko zwiększa możliwości rozwoju i efektywność całej organizacji, lecz także podnosi morale jednostek. Inwestycja w zatrudnionego człowieka sprawia, że ta osoba czuje się doceniona w oczach przedsiębiorcy. Taka polityka firmy skutkuje tym, że rozwijają się kontakty międzyludzkie i nie trzeba zaczynać ich często od nowa. Pamiętać należy jednak, że inwestycja w zasoby ludzkie jest opłacalna jedynie wtedy, gdy są one odpowiednio wybrane, dlatego dział HR w każdym przedsiębiorstwie odgrywa tak znaczącą rolę.

W obecnych czasach, w szczególności na terenie Unii Europejskiej, przedsiębiorstwa dysponują wieloma narzędziami rozwijania zasobów ludzkich. Władze krajów członkowskich, zauważając tendencję i znaczenie czynnika ludzkiego zarówno w przedsiębiorstwie, jak i gospodarce jako całości, przeznaczają ogromne kwoty na rozwój tej dziedziny. Liczne projekty i dofinansowania nastawione są na ten cel. Doskonałym przykładem jest unijny program „Kapitał ludzki”, który wychodzi naprzeciw potrzebom przedsiębiorców w rozwoju kapitału ludzkiego w firmach. Instytucje i organizacje państw członkowskich UE, w tym także Polska, otwierają się w ten sposób na nowe wyzwania i możliwości. Istnieje sześć głównych celów programu (www: Europejski Fundusz Społeczny, 2014):

- podniesienie poziomu aktywności zawodowej oraz zdolności do zatrudnienia osób bezrobotnych i biernych zawodowo;

- zmniejszenie obszarów wykluczenia społecznego;

- poprawa zdolności adaptacyjnych pracowników i przedsiębiorstw do zmian zachodzących w gospodarce; 
- upowszechnienie edukacji społeczeństwa na każdym etapie kształcenia przy równoczesnym zwiększeniu jakości usług edukacyjnych i ich silniejszym powiązaniu z potrzebami gospodarki opartej na wiedzy;

- zwiększenie potencjału administracji publicznej w zakresie opracowywania polityk i świadczenia usług wysokiej jakości oraz wzmocnienie mechanizmów partnerstwa;

- $\quad$ wzrost spójności terytorialnej.

Najważniejsza dla przedsiębiorstw jest realizacja trzech celów z powyższego zestawienia. Najbardziej potrzebne jest nauczenie się adaptacji firm do zmian zachodzących w gospodarce. Przedsiębiorstwa niepotrafiące korygować swoich działań w stosunku do gospodarki mogą stracić wiele szans rozwoju, ale także swój udział w rynku. W obecnych czasach jest to o tyle ważne, gdyż takie zmiany są współcześnie powszechnym zjawiskiem. Podniesienie aktywności zawodowej jest kolejną możliwością rozwoju całego przedsiębiorstwa, gdyż im więcej pracujących, tym konkurencja na rynku pracy większa, a władze organizacji mogą wybrać lepszy zespół pracowniczy. Wiąże się to także z obniżeniem kosztów stałych w przypadku dużej aktywności zawodowej. Wzrost spójności terytorialnej wpływa na zacieranie się granic, szybszy przepływ informacji i towarów. W wielu sektorach gospodarki osiągnięcie tego celu zwiększa możliwości przedsiębiorstw do współpracy. Organizacje w sytuacji spójności terytorium nie muszą kontrolować pozaekonomicznych czynników gospodarczych, a wybór partnerów biznesowych odbywa się przy ścisłej konkurencji (Ciekanowski, 2012, s. 98).

Według stanu na koniec marca 2013 roku w ramach programu „Kapitał ludzki” zawarto 39,1 tysięcy umów o dofinansowanie realizacji projektów o łącznej wartości 42,3 mld złotych. Przedstawione poniżej dane obrazują wzrost znaczenia kapitału ludzkiego w gospodarce państwa i przedsiębiorstwa w latach 2010-2012 (Ministerstwo Rozwoju Regionalnego, 2007). Unia Europejska, dostrzegając możliwości rozwoju, jakie dają inwestycje w kapitał ludzi, wydaje ogromne pieniądze na ten cel. Przedsiębiorstwa z Polski powinny wykorzystać daną im szansę, gdyż nie robiąc tego, zmniejszają swoje możliwości rozwoju oraz mogą przestać być konkurencyjne w stosunku do organizacji biorących udział w programie. Polskie firmy, chcąc dogonić Zachód oraz nawiązać walkę o zagranicznego klienta, muszą rozwinąć do tej pory niedoceniany kapitał ludzki. Programy Unii Europejskiej takie jak „Kapitał ludzki” idealnie wpisują się w politykę przedsiębiorstwa nastawioną na rozwój organizacji jako całości. Polacy niestety wypadają bardzo słabo na tle innych narodów w zestawieniu wskaźniku kształcenia ustawicznego. Wynik wynosi 4,7, a średnia UE to 9,5 („Dziennik Gazeta Prawna”, 2011, s. 5). Wskaźnik ten opisuje uczenie się ludzi dorosłych przez całą długość ich aktywności zawodowej. Obrazuje także, jakie cele polityki rozwoju zasobów ludzkich powinny wybierać władze polskich przedsiębiorstw. Dokładna realizacja założeń misji przedsiębiorstw pozwoli na zmniejszenie różnic i ekspansję polskich firm na rynki zachodnie. Przed podjęciem ważnej decyzji, 
w jaki segment zasobów ludzkich organizacji inwestować, przedsiębiorca musi przeanalizować sytuację całej firmy. Znalezienie niedoborów i niewystarczających kompetencji pracowników jest bardzo trudnym zadaniem, ponieważ wpływa na to wiele czynników. W tabeli 1 przedstawiono za „Gazetą Prawną” zestawienie tematyki szkoleń, w jakie przedsiębiorca w Polsce powinien inwestować, gdzie są niedobory we współczesnych organizacjach (dane w skali od 0 do 10).

Tabela 1. Zestawienie tematyki szkoleń

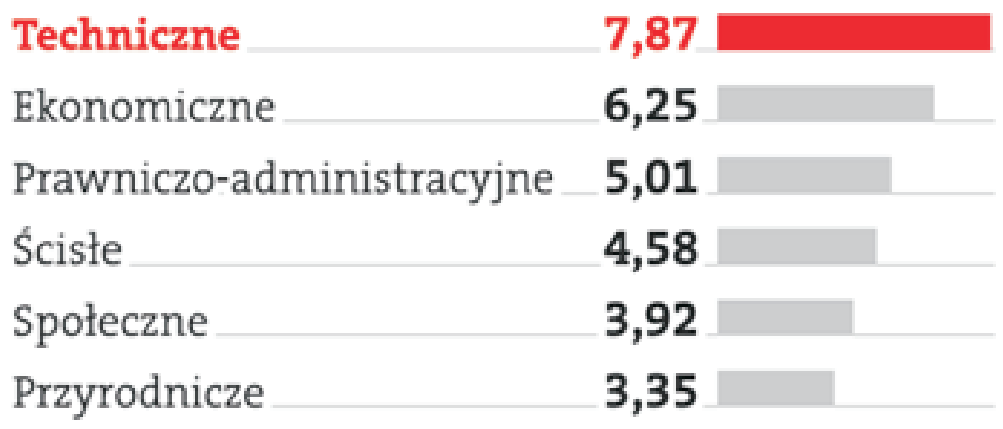

Źródło: „Gazeta Prawna”, artykuł Inwestycje w kapitał z 30 czerwca 2015 r.

\section{Procesy personalne}

Zarządzanie zasobami ludzkimi przybiera we współczesnych organizacjach formę mniej lub bardziej zaplanowanej konfiguracji, którą tworzą określone procesy personalne (kadrowe). Sposób wyodrębnienia oraz klasyfikacja tych procesów jest kwestią umowną i zależy od takich czynników jak wielkość przedsiębiorstwa, jego struktura organizacyjna i lokalizacja, branża oraz przyjęta przez kierownictwo filozofia zarządzania. Jednym z najprostszych podziałów jest wyodrębnienie trzech głównych procesów personalnych:

- wchodzenia ludzi do organizacji,

- funkcjonowania ludzi w organizacji,

- wychodzenia ludzi z organizacji.

W ramach tych trzech procesów można wyodrębnić wiele subprocesów, a następnie należy określić dla nich cele, odbiorców (klientów) oraz osoby odpowiedzialne za realizację procesu. Trzeba również ustalić mierniki efektywności procesów, które powinny się odnosić do kosztów, czasu trwania procesu, wydajności i jakości. Do procesów personalnych możemy zaliczyć:

- planowanie zasobów ludzkich,

- kształtowanie stanu i struktury personelu, 
- zarządzanie efektywnością pracy,

- kształtowanie wynagrodzeń,

- rozwój zasobów ludzkich,

- kształtowanie warunków i stosunków pracy,

- administrowanie sprawami personalnymi,

- doskonalenie organizacji i zarządzania funkcją personalną.

W realizacji poszczególnych procesów personalnych wykorzystuje się wiele narzędzi o różnym stopniu złożoności, które tworzą instrumentarium menedżera, konsultanta i badacza. Narzędzia te składają się na wymiar instrumentalny zarządzania zasobami ludzkimi, którego ulepszanie polega na doskonaleniu istniejących technik, a także wprowadzaniu kolejnych - nowych. Niektóre z tych technik mogą być wykorzystywane do rozwiązywania różnych kwestii powstających w obszarze funkcji personalnej.

Zmiany w otoczeniu organizacji stwarzają dla niej szereg konkurencyjnych wyzwań, co oznacza, że zarządzanie zasobami ludzkimi musi być włączone w proces tworzenia nowych możliwości.

\section{Podsumowanie}

Zasoby ludzkie w organizacji stanowią jej najważniejszy czynnik. Wiedza i umiejętności pracowników przekładają się na wyniki finansowe firmy. Inwestycje w kapitał ludzki otwierają wielkie możliwości rozwoju w każdym przedsiębiorstwie, ale jednocześnie ich brak sprawia, że organizacja stoi w miejscu. Zmniejszająca się konkurencyjność produktów, wzrost kosztów produkcji oraz ograniczanie możliwości przedsiębiorstwa do rozwoju wobec innych podmiotów na rynku to jedne z efektów złej polityki personalnej. Trzeba podkreślić, że przed inwestycją w zespół pracowniczy przedsiębiorstwo musi znaleźć odpowiednich ludzi. Jest to kluczowy element rozwoju w ujęciu długookresowym. Ten czynnik jest fundamentem dobrze funkcjonującej organizacji. Dlatego rozwój działów HR w firmach jest tak bardzo istotny, gdyż wyselekcjonowanie właściwych cech, umiejętności i doświadczenia u kandydatów do objęcia różnych stanowisk w organizacji wymaga bardzo dużej wiedzy. Odpowiednio wybrany zespół oraz inwestowanie w jego rozwój nie wystarczy, żeby osiągnąć zamierzone skutki, gdyż należy skupić się także na kierowaniu ludźmi. Każde przedsiębiorstwo powinno być zarządzane przez kompetentne osoby, co procentuje we wszystkich aspektach działalności organizacji. Zasoby ludzkie generują znaczącą część zysków firmy, dlatego umniejszanie ich znaczenia, gdy celem przedsiębiorstwa jest maksymalizacja zysków, jest bezpodstawne. Zarządzanie zasobami ludzkimi pozwala zwiększyć możliwości jednostek. Poprzez narzędzia takie jak motywowanie i system wynagrodzeń pracodawcy zachęcają członków zespołu do wytężonej pracy i co za tym idzie, zwiększają swój zysk. Aby zasoby ludzkie rozwijały 
się w szybkim tempie, nie można poprzestać na stosowaniu jedynie finansowych sposobów motywacji pracowników. Oferowanie licznych przywilejów, takich jak dłuższe urlopy macierzyńskie, dogodniejsza opieka zdrowotna oraz wiele innych, zwiększa satysfakcję ludzi pracujących w firmie, co przekłada się na większą chęć i energię do pracy oraz w efekcie zwiększenie możliwości produkcyjnych i efektywności. Obecnie przedsiębiorcy mogą korzystać z ogromu ofert szkoleń, warsztatów i innych sposobów podnoszenia kwalifikacji pracowników. Nawet władze Unii Europejskiej, dostrzegając potencjał i znaczenie czynnika ludzkiego w organizacji, tworzą projekty inwestycyjne. Poprzez dofinansowanie przedsiębiorstw zwiększają atrakcyjność terenu oraz wpływają na sytuację makroekonomiczną państw członkowskich. Przykładem takiej działalności jest wspomniany wyżej program „Kapitał ludzki”, który realizowany na terenie UE już przynosi wymierne efekty. Inwestowanie wielkich pieniędzy w ten sektor gospodarki Polski, sięgających prawie 45 mld złotych, sprawia, że pracownicy czują się doceniani i ciągle się rozwijają. Wykorzystując nowo poznane umiejętności, poprawiają sytuację firm, w których są zatrudnieni. Polskie przedsiębiorstwa nie do końca dostrzegają jednak potencjał drzemiący w zasobach ludzkich, dlatego też odstają od innych krajów. Kapitał ludzki, jak wcześniej opisałem, zapewnia rozwój oraz zyski organizacji. Jest to o tyle istotny czynnik, że bez niego nie jest możliwy nawet jeden krok do przodu. Polskie przedsiębiorstwa, wykorzystując szansę, jaką daje rozwój zasobów ludzkich oraz dbanie o nie, same mogą poprawić koniunkturę rynku polskiego oraz dodatkowo wspomóc rozwój całego państwa. Wybór zasobów ludzkich jako najważniejszego czynnika w każdej organizacji powinien być celem nadrzędnym.

\section{LITERATURA}

[1] Ciekanowski Z., Determinanty bezpieczeństwa personalnego w zarządzaniu zasobami ludzkimi w nowoczesnej organizacji, PWST-E, Jarosław 2014.

[2] Ciekanowski Z., Jakość w zarządzaniu zasobami ludzkimi, PWST-E, Jarosław 2013.

[3] Ciekanowski Z., Narzędzia w zarządzaniu zasobami ludzkimi, DANMAR, Warszawa 2012.

[4] StANiEwski M.W., Zarządzanie zasobami ludzkimi a zarządzanie wiedza w przedsiębiorstwie, Wizja Warszawa 2008.

[5] Ludwiczyński A., Król H., Zarzq̨dzanie zasobami ludzkimi, tworzenie kapitału ludzkiego organizacji, PWN, Warszawa 2008.

[6] Pocztowski A., Najlepsze praktyki zarządzania zasobami ludzkimi w Polsce, Oficyna Ekonomiczna, Kraków 2003.

[7] Griffin R.W., Podstawy zarządzania organizacjami, PWN, Warszawa 1996.

[8] Lірка A., Inwestycje w kapitał ludzki organizacji w okresie koniunktury i dekoniunktury, Oficyna Wolters Kluwer, Warszawa 2010.

[9] Armstrong M., Zarządzanie zasobami ludzkimi, Oficyna Ekonomiczna, Kraków 2002.

[10] Issacson W., 2012, Steve Jobs, Insignis, Warszawa.

[11] Doвıja D., Pomiar i sprawozdawczość kapitału intelektualnego przedsiębiorstwa, Wyższa Szkoła Przedsiębiorczości i Zarządzania, Warszawa 2003. 
[12] Domański S., Kapitał ludzki i wzrost gospodarczy, PWN, Warszawa 1993.

[13] Drucker P.F., Zarządzanie w XXI wieku - wyzwania, New Media, Warszawa 2000.

[14] Hejduk I., Przedsiębiorstwo przyszłości, Difin, Warszawa 2000.

[15] Kożusznık B., Kapitał ludzki w dobie integracji i globalizacji, CEDEWU, Warszawa 2009.

[16] Łukaszewicz G., Kapitał ludzki organizacji, PWN, Warszawa 2009.

[17] Publikacja Ministerstwa Rozwoju Regionalnego, Program Kapitał Ludzki, Warszawa 2007.

[18] „Dziennik Gazeta Prawna”, Inwestycje w kapitał ludzki, dodatek do DGP nr 125(3011) z 30 czerwca, 2011.

\section{NETOGRAFIA}

[1] Europejski Fundusz Społeczny, Program Kapitał Ludzki, http://www.efs.gov.pl/. 
